\title{
The Profile Analysis of Lactic Acid Bacteria (LAB) from Sumbawa White Honey and Its Potential Producing Antibacterial Compounds
}

\author{
Baso MANGUNTUNGI ${ }^{1}{ }^{1 *}$, Apon Zaenal MUSTOPA ${ }^{2}$, Lita MEILINA ${ }^{2}$, \\ Maritsa NURFATWA ${ }^{2}$, Leggina Rezzy VANGGY ${ }^{1}$, Shasmita IRAWAN ${ }^{3}$, \\ Mohamed Sahrul TAMZIL ${ }^{3}$, Tegar APRILIAN ${ }^{1}$, Yulianti ${ }^{1}$, \\ Arsyadila Sophia FIDDUHA ${ }^{4}$ and Intan Nurani WERSIAN ${ }^{4}$
}

${ }^{I}$ Department of Biotechnology, Faculty of Biotechnology, Universitas Teknologi Sumbawa, Sumbawa 84371, West Nusa Tenggara, Indonesia

${ }^{2}$ Research Center for Biotechnology, Indonesian Institute of Sciences, Cibinong,

Bogor 16911, West Java, Indonesia

${ }^{3}$ Graduate School of Biotechnology, IPB University, Bogor 16680, West Java, Indonesia

${ }^{4}$ Islamic Integrated Senior High School Samawa Cendekia (SMA IT Samawa Cendekia) Sumbawa 84371, West Nusa Tenggara, Indonesia

('Corresponding author's e-mail: baso.manguntungi@uts.ac.id)

Received: 4 April 2021, Revised: 9 May 2021, Accepted: 16 May 2021

\begin{abstract}
Honey acts as an antibacterial without side effects, and also contains antiseptic substances which function to inhibit bacterial growth. This study aimed to isolate the Lactic Acid Bacteria (LAB) in Sumbawa white honey and the bioactive compounds produced as pathogenic antibacteria. The $1^{\text {st }}$ stage in this study was the isolation of lactic acid bacteria (LAB) in Sumbawa white honey, then continued with a grading test, morphological test, catalase test, methyl red test, and the last test, namely the antimicrobial test against 5 pathogenic bacteria (Salmonellatyhposa, Staphylococcus aureus, Escherichia coli, Enterobacter ludwigii, and Leclerciaadecarboxylata). Data analysis was performed using the Analysis of variance (ANOVA) test at a confidence level of 0.05 with SPSS 24. Based on the results of sequencing analysis, it was found that the 5 selected isolates were Enterococcus faecium species. The Enterococcus faecium species obtained from the sequencing results had different strains. The accession numbers of the 5 Enterococcus faecium were: Isolate-03 with a percentage of $97.29 \%$ (accession number: KU324920.1), Isolate-07 has a percent identity of $97.36 \%$ (accession number: MF108201.1), Isolate-09 of $97.73 \%$ (accession number: CP041261.3), Isolate-20 with a percentage of $96.40 \%$ (accession number: MN511819.1), and Isolate-24 with a percentage of $98.61 \%$ (accession number: KM495938.1). These isolates can inhibit the growth of all tested pathogenic bacteria treated with $100 \%$ LAB metabolites and were not significantly different $(p>0.05)$ compared to a positive control (Ampicillin).
\end{abstract}

Keywords: Antibacterial compounds, Lactic Acid Bacteria (LAB), Sumbawa white honey

\section{Introduction}

Sumbawa is one of the honey-producing areas in Indonesia, one of the types of honey produced is Sumbawa White Honey, which is produced by Apis mellifera. These bees are found around Mount of Tambora, in Dompu Regency. Sumbawa white honey produced by Apis mellifera also has very good benefits, the same as other Sumbawa honey, such as the black honey from Sumbawa produced by Trigona spp [1], and also honey produced by Apisdorsata. But until now, research on white honey is still rare. 
http://wjst.wu.ac.th

LAB is a type of microbe that can live in acidic conditions, especially in food ingredients. LAB is a group of gram-positive bacteria that do not produce spores. LAB can produce lactic acid as a result of the fermentation of food materials such as sugar and carbohydrates [2]. In general, LAB has the characteristic of reacting negatively to the catalase test and having a positive reaction to gram staining [3]. Several genera of known lactic acid bacteria are Lactobacillus, Streptococcus, Enterococcus, Pediococcus, Tetragenococcus, Leuconostoc, and Lactococcus [4]. In addition, to producelactic acid, LAB is also known to be able to produce antimicrobial compounds such as bacteriocins, hydrogen peroxide, and organic acids (citric, lactic, etc.) [5].

Bacteriocins are compounds used as preservatives, while the acetic acid, lactic acid, and propionic acid are antimicrobial agents that are widely used in the food industry [6]. LAB can inhibit pathogenic microbes. Naturally, LAB can be found in various habitats such as fermented food and the human digestive tract. So far, it is known that LAB is not pathogenic and safe for consumption so that it can be used to improve human health. The availability of LAB isolated from domestic sources is still lacking, so exploration of lactic acid bacteria is needed to increase the collection of lactic acid bacteria isolates. Lactic acid bacteria can be obtained by utilizing sources containing lactic acid bacteria.

\section{Materials and methods}

\section{Isolation of LAB}

The isolation of LAB from Sumbawa white honey refers to Manguntungia et al. [7]. A total of $1 \mathrm{~mL}$ of white honey was homogenized into $5 \mathrm{~mL}$ of MRS broth medium (de Man, Rogosa and Sharpe medium; Merck, USA) and incubated for $24 \mathrm{~h}$ at $37^{\circ} \mathrm{C}$. After $24 \mathrm{~h}$, a serial dilution of up to $10^{-5}$ was made, samples with a dilution of $10^{-3}, 10^{-4}$, and $10^{-5}$ were spread on MRS agar medium and incubated for $24 \mathrm{~h}$ at $37^{\circ} \mathrm{C}$. The representative colonies were then randomly selected to be purified on the same medium and maintained at $4{ }^{\circ} \mathrm{C}$.

\section{The profile analysis of $\mathrm{LAB}$}

All bacterial colonies obtained were then identified based on morphological and physiological parameters. Identification of LAB profiles was based on morphological characteristics, including bacterial shapes, colony colors, colony margins, and elevation. Microscopic analysis was performed using gram stain and observed under a light microscope at 100× magnification. Physiological tests include the catalase test and methyl red test [8]. Methyl Red (MR) test aims to detect the ability of organisms to produce and maintain stable acids and products from glucose fermentation.

\section{Antimicrobial analysis}

Some isolates were selected based on the results of morphological, biochemical, and physiological tests, namely Isolate-03, Isolate-07, Isolate-09, Isolate-20, and Isolate-24 grown on $50 \mathrm{~mL}$ of liquid MRS media. The bacterial isolates were then cultivated at $37^{\circ} \mathrm{C}$ for 3 days with a shaking rate of $1 \mathrm{~g}$. The antimicrobial test used the agar well diffusion method. The bacteria test used were pathogenic bacteria Salmonella tyhposa, Staphylococcus aureus, Escherichia coli, Enterobacter ludwigii, and Leclerciaadecarboxylata. The antimicrobials used were secondary metabolites produced by lactic acid bacteria from Sumbawa white honey. Positive control of test bacteria using ampicillin $(50 \mu \mathrm{g} / \mathrm{mL})$. A total of $3 \mathrm{~mL}$ (dilution has been carried out) of test bacteria was added to $20 \mathrm{~mL}$ nutrient agar media then poured into a sterile petri dish, waiting to solidify. After compacting a well is made with a diameter of 6 $\mathrm{mm}$. The secondary metabolites were put into the well as much as $30 \mu \mathrm{L}$ and then incubated at $37^{\circ} \mathrm{C}$. Obstacle zone observations were carried out at $16 \mathrm{~h}$ [9].

\section{DNA isolation}

$1.5 \mathrm{~mL}$ of liquid culture was taken in a microtube and centrifuged at $6000 \times \mathrm{g}$ for $10 \mathrm{~min}$ at $4{ }^{\circ} \mathrm{C} .1 .5$ $\mathrm{mL}$ of liquid culture was added to the pellet and re-centrifuged at $6000 \times \mathrm{g}$ for $10 \mathrm{~min}$ at $4{ }^{\circ} \mathrm{C}$. The supernatant was discarded and the pellet was added with $500 \mu \mathrm{L}$ TE buffer $\mathrm{pH} 8$ and $40 \mu \mathrm{L}$ Lysozyme (60 $\mathrm{mg} / \mathrm{mL}$ ), then incubated at $37^{\circ} \mathrm{C}$ for $60 \mathrm{~min}$. After incubation, $200 \mu \mathrm{L} 10 \% \mathrm{SDS}, 100 \mu \mathrm{L} 5 \mathrm{M} \mathrm{NaCl}, 80$ 
$\mu \mathrm{L} 10 \% \mathrm{CTAB}$ were added to a microtube and then incubated at $60{ }^{\circ} \mathrm{C}$ for 30 min (invert microtube every $10 \mathrm{~min}$ ). $700 \mu \mathrm{L}$ of chloroform $1: 1$ was added and centrifuged at $13000 \times g$ for $10 \mathrm{~min}$ at $4{ }^{\circ} \mathrm{C}$. The supernatant was transferred to a new microtube and added $0.6 \times$ volume of isopropanol, then incubated for $2 \mathrm{~h}$ at $-20{ }^{\circ} \mathrm{C}$. After incubation, the microtube was centrifuged at $13000 \times g$ for $10 \mathrm{~min}$, at $4{ }^{\circ} \mathrm{C}$. The supernatant was discharged. Pellets were added with $1 \mathrm{~mL}$ of ethanol $70 \%$ and centrifuged at $13000 \times g$ for $10 \mathrm{~min}, 4^{\circ} \mathrm{C}$. The supernatant was discarded and the pellet is dried overnight. The pellets were added $30 \mu \mathrm{L}$ ddH2O and $5 \mu \mathrm{L}$ RNAse $(1 \mathrm{mg} / \mathrm{mL})$ and then incubated at $37^{\circ} \mathrm{C}$ for $60 \mathrm{~min}$. After that, the results of DNA isolation were stored at a low temperature to avoid DNA degradation [10] and analyzed with gel electrophoresis on $2 \%(\mathrm{w} / \mathrm{v})$ agarose gel by using $\times$ TAE buffer. Then the gel was stained in ethidium bromide solution and using a UV transilluminator to analyze it.

\section{S rRNA PCR and sequencing analysis}

PCR16S rRNA is a step to identify LAB strains using a 16S rRNA universal primer. The primer sequences used are 8F (5'-AGAGTTTGATCATGGCTCAG-3') and 15R (5'AAGGAGGTGATCCAACCGCA-3'). Positions 1541 to $1522 \mathrm{bp}$ are used to amplify the overall fragment length of $16 \mathrm{~S}$ rRNA bacteria [11]. The reaction mixture of PCR includes $\mathrm{ddH}_{2} \mathrm{O} 38.5 \mu \mathrm{L}, 5 \mathrm{x}$ MyTaq Green $7.5 \mu \mathrm{L}, 1 \mu \mathrm{L}$ of each primer, DNA templates (LAB genome) $2 \mu \mathrm{L}$ so that the total volume is $50 \mu \mathrm{L}$. The PCR conditions were $96{ }^{\circ} \mathrm{C}$ for $5 \mathrm{~min} ; 35$ cycles consisting of $96{ }^{\circ} \mathrm{C}$ for $1 \mathrm{~min}, 55^{\circ} \mathrm{C}$ for 30 $\mathrm{s}$, and $72{ }^{\circ} \mathrm{C}$ for $1 \mathrm{~min}$; and $72{ }^{\circ} \mathrm{C}$ for $7 \mathrm{~min}$. The PCR products were subjected to electrophoresis gel on 1 $\%$ agarose gel, followed by ethidium bromide staining. Sequencing results were analyzed using the Basic Local Alignment Search Tool (BLAST) in the NCBI and MegaX software.

\section{Data analysis}

The test was carried out with a completely randomized design (CRD) with 3 replications. Data were tested by Analysis of variance (ANOVA) with a confidence level of .05 and SPSS 24.0 software.

\section{Result and discussion}

\section{Morphological characterization of LAB from Sumbawa white honey}

The LAB isolation confirmed some bacteria presenced in the samples, and the high survival LAB was identified by the existence of colonies that grow even at $10^{-5}$ dilutions (Figure 1). Unlike other bacteria, the presence of LAB is generally not pathogenic. Olofsson et al. [12] stated that honey bees have formed an interaction with some microbial communities and this can be found in all parts of the body, especially the gut (gut microbiota), hive, and honey bees. Although honey is known to have antimicrobial activity, some microbes can adapt and survive in honey, especially LAB [13]. European honey bees (Apis mellifera) are known to be host microbial communities which mostly consist of 3 main phyla (Firmicutes, Proteobacteria, and Actinobacteria) [14]. The presence of these bacteria is thought to have originated from flowers visited by bees [15]. Lactobacillus sp. is an example of bacteria associated with pollen flowers that can be found in honey [16]. The characteristics of honey which have a high sugar content plus a $\mathrm{pH}$ ranging from 3.2 - 4.5 make pathogenic bacteria and fungi impossible to grow [17]. When compared with conditions in fermented foods, this characteristic of honey is a suitable environment for several lactic acid bacteria that require a low $\mathrm{pH}$ environment [18]. Furthermore, several LAB species are known to be capable of producing bioactive compounds such as organic acids, hydrogen peroxide, diacetyl, bacteriocins, antimicrobial peptides, and antibiotics. 
A

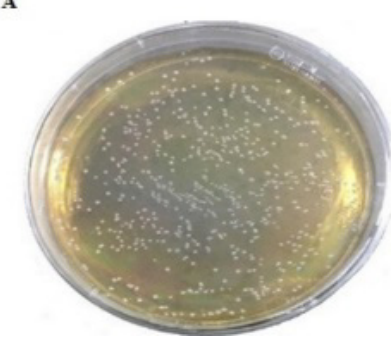

B

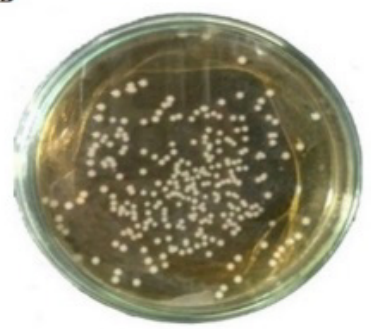

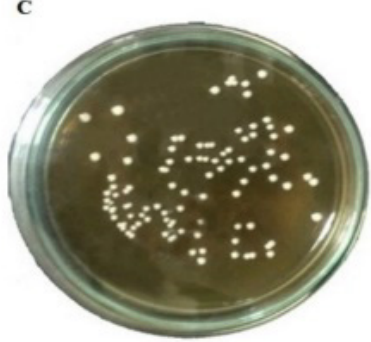

Figure 1 Colonies of isolated bacteria grown on MRS medium in order from several dilutions. A) $10^{-3}$ dilution; B) $10^{-4}$ dilution; C) dilution $10^{-5}$.

Some bacteria that grow from isolation are believed to be lactic acid bacteria. The use of MRS medium selectively eliminates the growth of bacteria other than LAB due to low $\mathrm{pH}$ conditions plus the presence of inhibitors such as sorbic acid [19,20]. From the screening results, 35 bacterial isolates were obtained. Morphological analysis was carried out to determine the characteristics of each isolate, and the results showed that all isolates had the same colony characteristics. Further testing was carried out to determine the microscopic appearance of the morphology of each isolate. Gram staining showed that the isolates consistently showed relatively the same morphological characteristics, gram-positive in the form of rods. The morphological appearance of the 35 isolates selected as the desired LAB candidates is shown in Table 1.

Microscopic observation strengthens the test using MRS medium for the selection of LAB in honey samples. In general, LAB has characteristics; Gram-positive, non--spore-forming, stem and cocci shaped, and catalase-negative [21,22]. However, further testing needs to be done to identify all the isolates obtained.

Table 1 Morphological test results on bacteria from Sumbawa white honey.

\begin{tabular}{|c|c|c|c|c|c|c|c|c|c|}
\hline $\begin{array}{l}\text { Isolate } \\
\text { species }\end{array}$ & $\begin{array}{c}\text { Bacteria } \\
\text { shape }\end{array}$ & Color & $\begin{array}{c}\text { Colony } \\
\text { shape }\end{array}$ & Margin & $\begin{array}{l}\text { Isolate } \\
\text { species }\end{array}$ & $\begin{array}{c}\text { Bacteria } \\
\text { shape }\end{array}$ & Color & $\begin{array}{c}\text { Colony } \\
\text { shape }\end{array}$ & Margin \\
\hline 1 & Cocci & White & Circular & Entire & 19 & Cocci & White & Circular & Entire \\
\hline 2 & Cocci & White & Circular & Entire & 20 & Cocci & White & Circular & Entire \\
\hline 3 & Cocci & White & Circular & Entire & 21 & Cocci & White & Circular & Entire \\
\hline 4 & Cocci & White & Circular & Entire & 22 & Cocci & White & Circular & Entire \\
\hline 5 & Cocci & White & Circular & Entire & 23 & Cocci & White & Circular & Entire \\
\hline 6 & Cocci & White & Circular & Entire & 24 & Cocci & White & Circular & Entire \\
\hline 7 & Cocci & White & Circular & Entire & 25 & Cocci & White & Circular & Entire \\
\hline 8 & Cocci & White & Circular & Entire & 26 & Cocci & White & Circular & Entire \\
\hline 9 & Cocci & White & Circular & Entire & 27 & Cocci & White & Circular & Entire \\
\hline 10 & Cocci & White & Circular & Entire & 28 & Cocci & White & Circular & Entire \\
\hline 11 & Cocci & White & Circular & Entire & 29 & Cocci & White & Circular & Entire \\
\hline 12 & Cocci & White & Circular & Entire & 30 & Cocci & White & Circular & Entire \\
\hline 13 & Cocci & White & Circular & Entire & 31 & Cocci & White & Circular & Entire \\
\hline 14 & Cocci & White & Circular & Entire & 32 & Cocci & White & Circular & Entire \\
\hline 15 & Cocci & White & Circular & Entire & 33 & Cocci & White & Circular & Entire \\
\hline 16 & Cocci & White & Circular & Entire & 34 & Cocci & White & Circular & Entire \\
\hline 17 & Cocci & White & Circular & Entire & 35 & Cocci & White & Circular & Entire \\
\hline 18 & Cocci & White & Circular & Entire & & & & & \\
\hline
\end{tabular}




\section{Physiological characterization of LAB from Sumbawa white honey}

Physiological tests of all isolates mostly showed the biochemical characteristics of LAB. Catalase testing is carried out to determine the ability of bacteria to produce the catalase enzyme which plays a role in the hydrolysis of hydrogen peroxide. The enzyme is produced by aeoro-tolerant bacteria. Stiles and Holzapfel [22] stated that one of the characteristics of LAB is a false negative, the enzyme produced is not catalase but peroxidase. However, from the test results obtained, some isolates showed catalase activity (Table 2). Whittenbury [23] stated that some LAB species such as Lactobacillus, Leuconostoc, Streptococcus, and Pediococcus showed catalase activity. It is lead by their ability to synthesize apoenzyme, but unable for catalase prosthetic groups. Some other LAB groups were also reported to have the ability in producing pseudo catalase activity.

Table 2 The result of physiological tests on bacteria of Sumbawa white honey.

\begin{tabular}{cccccccc}
\hline $\begin{array}{c}\text { Isolates } \\
\text { Code }\end{array}$ & $\begin{array}{c}\text { Gram } \\
\text { staining }\end{array}$ & $\begin{array}{c}\text { Catalase } \\
\text { test }\end{array}$ & $\begin{array}{c}\text { Methyl } \\
\text { red }\end{array}$ & $\begin{array}{c}\text { Isolates } \\
\text { code }\end{array}$ & $\begin{array}{c}\text { Gram } \\
\text { staining }\end{array}$ & $\begin{array}{c}\text { Catalase } \\
\text { test }\end{array}$ & $\begin{array}{c}\text { Methyl } \\
\text { red }\end{array}$ \\
\hline 01 & + & + & + & 19 & + & - & - \\
02 & + & - & + & 20 & + & - & + \\
03 & + & - & + & 21 & + & + & + \\
04 & + & + & - & 22 & + & - & - \\
05 & + & + & + & 23 & + & - & + \\
06 & + & + & + & 24 & + & - & + \\
07 & + & - & + & 25 & + & - & + \\
08 & + & + & + & 26 & + & - & + \\
09 & + & - & + & 27 & + & - & + \\
10 & + & - & + & 28 & + & - & + \\
11 & + & - & - & 29 & + & - & + \\
12 & + & + & + & 30 & + & - & - \\
13 & + & - & + & 31 & + & + & + \\
14 & + & + & + & 32 & + & - & - \\
15 & + & - & + & 33 & + & + & + \\
16 & + & + & + & 34 & + & - & - \\
17 & + & - & + & 35 & + & + & + \\
18 & + & + & - & 35 & + & + \\
\hline
\end{tabular}

Glucose fermentation activity by LAB was detected using the methyl red test. The basic principle of the test is to detect glucose degradation products during fermentation. Some bacteria can utilize glucose and convert it into stable acids such as lactic acid, acetic acid, or formic acid as end products. The initial stage of this process is the conversion of glucose to pyruvic acid, which is then metabolized via the mixed acid pathway to produce a stable acid. The type of acid produced is different for each species, this depends on the specific enzymatic pathway present in bacteria. The resulting acid lowers the $\mathrm{pH}$ to 4.5 or lower, which is indicated by the color change of methyl red from yellow to red. The test in this study showed that almost all isolates gave positive results, while 8 isolates showed negative results. This indicates that the LAB species obtained from Sumbawa white honey are able to utilize the glucose molecule to form various stable acid compounds. As a composition, honey contains 4 types of sugar, namely, glucose, fructose, sucrose, and maltose [18,24]. Although it can utilize glucose as a carbon source, it is suspected that the fermentation activity by LAB is not as efficient as other fermentation products, considering that some components in honey are known to be bacteriostatic and possibly have an effect in inhibiting bacterial fermentation activity. However, this is sufficient to produce organic acids and lactic acid components which not only add to the distinctive taste of honey, especially Sumbawa honey but also possibly give additional properties to honey with bioactive activities. 
Molecular identification and clustering of phylogenetic trees of LAB in Sumbawa white honey

Among $35 \mathrm{LAB}$ candidates based on morphological and physiological analysis, 5 isolates were selected (Isolate-03, Isolate-07, Isolate-09, Isolate-20, and Isolate-24) which would be further analyzed. The analysis is in the form of molecular identification as well as secondary metabolite production, and pathogenic antibacterial activity tests of the resulting LAB secondary metabolites. The molecular analysis begins with the isolation of the bacterial genome, followed by detection with 16S rRNA, sequencing analysis, and analysis of phylogenetic trees. Following are the results of PCR detection on 5 randomly selected isolates (Figure 2).

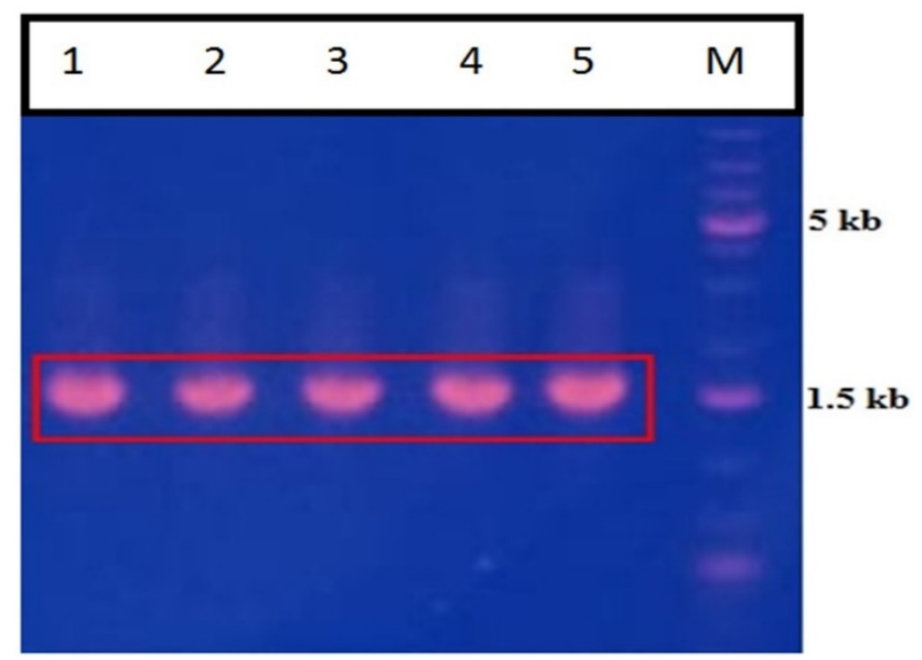

Figure 2 PCR results for 16S rRNA 5 selected isolates (Isolate-03: 1, Isolate-07: 2, Isolate-09: 3, Isolate 20: 4, Isolate24: 5 and M: DNA Marker)

A further test is LAB genome sequencing to determine the specific type of isolate by 16 s rRNA bacterial marker. Based on the results of sequence analysis, it was found that the 5 selected isolates were Enterococcus faecium, and gave different strains from each selected LAB genome (Table 3). Furthermore, phylogenetic analysis was carried out to see the closeness of the selected isolates from other strains. Taken together, the identified LAB strains in this study have to be proven on the next parameter analysis to support the previous study that suggested various strains of LAB could produce bacteriocins or antibacterial proteins on pathogenic microbes, and not limited to specific strain [25]. The presence of some LAB in honey products is thought to have originated from the polluting activity and this has formed an association with honey bees throughout evolutionary history. It appears that the honey bee and plants form a co-evolution. LAB obtains a niche where nutrients are available, and honey bees receive protection from pathogenic microbes [26]. 
http://wjst.wu.ac.th

Table 3 The results of 16S rRNA molecular identification.

\begin{tabular}{ccccc}
\hline No & Isolates code & Species (strain) & Identity & Accession number \\
\hline 1 & Isolate-03 & Enterococcus faecium Strain BagHom4 & $97.29 \%$ & KU324920.1 \\
2 & Isolate-07 & Enterococcus faecium Strain CAU9510 & $97.36 \%$ & MF108201.1 \\
3 & Isolate-9 & Enterococcus faecium Strain VVEswe-R & $97.73 \%$ & CP041261.3 \\
4 & Isolate-20 & Enterococcus faecium Strain AA4 & $96.40 \%$ & MN511819.1 \\
5 & Isolate-24 & Enterococcus faecium Strain gp21 & $98.61 \%$ & KM495938.1 \\
\hline
\end{tabular}

Moreover, Olofson et al. [13] stated that the diversity of LAB in bees did not come from flowers but from the gut microbiota, which was found in phylotypes of 6 species including the genus Lactobacillus and 4 species including Bifidobacterium. Environmental habitats may also facilitate the transfer of bacteria across the colony. The environments that are behaviorally connected, such as the nurse gut and the brood cells, may act as microbial hubs through which honey bees obtain, deposit, and propagate LAB within the hive to the next generation. Rokop et al. [15] stated that based on the results of the 16S rRNA analysis, some associated with honey bees and possibly transferred to honey and other products produced by bees, all belong to the Pasteurelaceae, Lactobacillus, and Bifidobacteriaceae.

The existence of various LAB strains in Sumbawa white honey seems to be influenced by the natural habitat of plants which are a source of nectar for bees, and indirectly this is thought to have contributed greatly to the diversity of lactic acid compounds and the products of LAB excretion in Sumbawa white honey. The correlated microbiome diversity in the Sumbawa white honey bee and preserved in the resulting honey product has the potential for further development to determine the efficacy of the fermented LAB isolate compounds obtained.

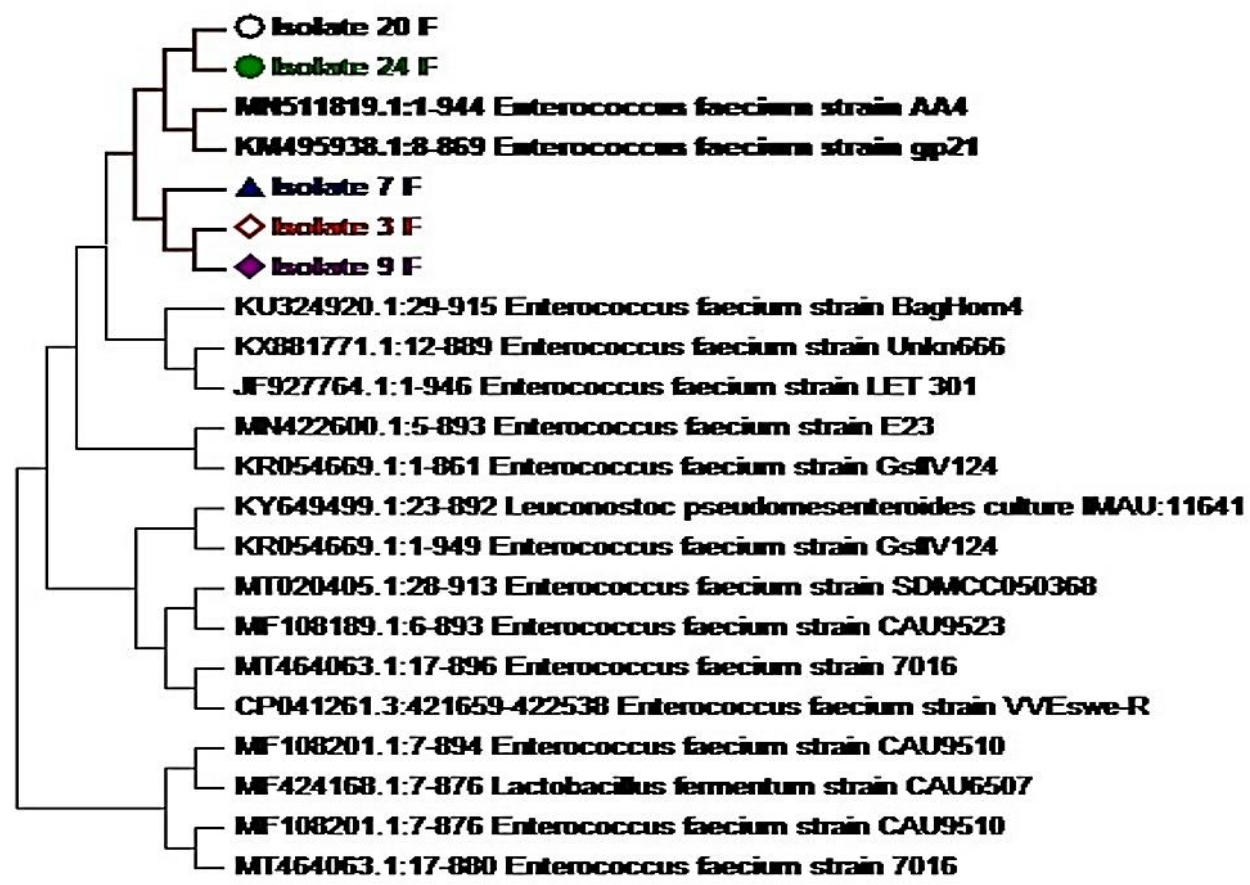

Figure 3 Results of phylogenetic tree analysis of 5 selected isolates. 


\section{Production of secondary metabolites of LAB from Sumbawa white honey}

Some isolates were selected based on the results of biochemical and physiological tests reproduced on the MSA broth medium. Cultivation carried out at $37^{\circ} \mathrm{C}$ for 3 days with a shaking rate of $1 \mathrm{~g}$ is expected to be able to produce lactic acid products during fermentation. Some organic acids will be released into the medium during the fermentation process, then testing for antibacterial activity can be carried out using a fermented supernatant. Abdel-Rahman et al. [27] stated that the optimal conditions for $\mathrm{LAB}$ growth in the fermentation stage depend on the procedure used, but in general LAB can grow in the $\mathrm{pH}$ range $3.5-10$ and temperatures of $5-45^{\circ} \mathrm{C}$. Based on the final product produced, LAB can be classified as homofermentative or heterofermentative. Homofermentative LAB has aldolase and produces lactic acid as the main end product. Whereas heterofermentative LAB produces side products other than lactic acid, therefore the maximum yield of lactic acid to glucose only reaches $0.5 \mathrm{~g} / \mathrm{g}$ or $1.0 \mathrm{~mol} / \mathrm{mol}$ [27].

Heterofermentative LAB uses the pentose monophosphate pathway, this pathway converts 6-carbon sugar (hexose) into carbonated sugar (pentose) and carbon dioxide which is catalyzed by several enzymes. Then, the resulting pentose is broken down into glyceraldehyde 3-phosphate and acetyl phosphate by phosphocytolase. Most heterofermentative LAB strains convert pentose sugar into lactic acid and by-products (for example, acetic acid) through the phosphocytolase pathway with lactic acid yield [27]. Reddy et al. [28] stated that most LAB species require complex nutrients, including vitamins, minerals, amino acids, peptides, and nucleotides to support their growth because LAB does not have varied biosynthetic capabilities. This is thought to be correlated with why LAB species can grow on honey, especially Sumbawa white honey, considering that honey grains a large number of components both minerals and vitamins as well as various sources of sugar. LAB can produce lactic acid as a result of the fermentation of food materials such as sugar and carbohydrates. Besides producing lactic acid, LAB is also known to be able to produce antimicrobial compounds such as bacteriocins, hydrogen peroxide, and organic acids such as citric acid and lactic acid. Bacteriocins are compounds used as preservatives, while the acetic acid, lactic acid, and propionic acid are antimicrobial agents that are widely used in the food industry.

\section{Antibacterial bioprospection of secondary metabolite compounds of LAB against food pathogenic bacteria}

LAB can inhibit the growth of pathogenic bacteria, both as probiotics and through the resulting fermentation products which have roles as bacteriostatics and bacteriocides. Shamala et al. [29] stated that LAB activity as a probiotic is related to competition for adhesion receptors in the intestinal epithelium, competition for nutrients, antibacterial production and stimulation of the immune system. Lactic acid bacteria that grow in the intestine produce metabolites that will inhibit the growth of pathogens. Various organic acids produced also reduce intestinal $\mathrm{pH}$ which will inhibit other pathogenic bacteria from colonizing the intestine.

Supernatant testing of 5 selected LAB isolates was carried out on pathogenic microbes to see their effectiveness in inhibiting the growth of the tested bacteria. Some pathogenic bacteria used are common bacteria in antimicrobial testing, namely Salmonella typhi, Staphylococcus aureus, Escherichia coli. Besides that, testing was also carried out on the bacteria Enterobacter ludwigii and Leclercia adecarboxylata. E. ludwigii is known to be a common cause of infection in hospitals, apart from that it is a cause of stomach, urinary tract, and meningeal infections [30]. Meanwhile, Leclercia adecarboxylata is usually isolated as part of the polymicrobial culture in immunocompetent patients. Although these bacteria are generally sensitive to most antibiotics there have been several reports of antibiotic-resistant strains [31]. Through initial testing with the agar well diffusion method, it was found that in general the supernatants of the 5 isolates were able to inhibit the growth of the tested bacteria (Table 4). 
http://wjst.wu.ac.th

Table 4 Inhibitory activity of pathogenic bacteria from the supernatant of selected isolates from MRS broth medium after 3 days of fermentation.

\begin{tabular}{|c|c|c|c|c|c|c|}
\hline \multirow{2}{*}{$\begin{array}{l}\text { Isolate } \\
\text { Code }\end{array}$} & \multirow{2}{*}{$\begin{array}{l}\text { Conc. } \\
\text { (ppm) }\end{array}$} & \multicolumn{5}{|c|}{ Inhibitory Zone Diameter of Pathogenic Bacteria (mm) } \\
\hline & & S. thyposa & S. aureus & E. coli & E. ludwigii & L.adecarboxylata \\
\hline \multirow{7}{*}{07} & 20 & $5 \pm 0.00^{\mathrm{b}}$ & $6.67 \pm 1.15^{\mathrm{b}}$ & $8 \pm 0.00^{b}$ & $8 \pm 0.00^{b}$ & $5.33 \pm 0.58^{b}$ \\
\hline & 40 & $7.67 \pm 0.58^{\mathrm{c}}$ & $9.33 \pm 0.58^{\mathrm{c}}$ & $9.67 \pm 0.58^{\mathrm{c}}$ & $9.67 \pm 0.58^{\mathrm{c}}$ & $6.33 \pm 0.58^{\mathrm{c}}$ \\
\hline & 60 & $11 \pm 1.00^{\mathrm{d}}$ & $12.33 \pm 0.58^{\mathrm{d}}$ & $13 \pm 0.00^{\mathrm{d}}$ & $11 \pm 0.00^{\mathrm{d}}$ & $11.33 \pm 0.58^{\mathrm{d}}$ \\
\hline & 80 & $12 \pm 1.73^{\mathrm{d}}$ & $14.33 \pm 1.00^{\mathrm{e}}$ & $14.33 \pm 0.58^{\mathrm{e}}$ & $13 \pm 0.00^{\mathrm{e}}$ & $13.67 \pm 0.58^{\mathrm{e}}$ \\
\hline & 100 & $14.67 \pm 1.53^{\mathrm{e}}$ & $17.67 \pm 0.58^{f}$ & $18.33 \pm 0.58^{f}$ & $15 \pm 0.00^{\mathrm{f}}$ & $18 \pm 0.00^{\mathrm{f}}$ \\
\hline & $\mathrm{K}+$ & $15.33 \pm 1.53^{\mathrm{e}}$ & $19.67 \pm 0.58^{\mathrm{g}}$ & $18.67 \pm 0.58^{f}$ & $19 \pm 0.58^{\mathrm{g}}$ & $18 \pm 0.00^{\mathrm{f}}$ \\
\hline & $\mathrm{K}^{-}$ & $0 \pm 0.00^{\mathrm{a}}$ & $0 \pm 0.00^{\mathrm{a}}$ & $0 \pm 0.00^{\mathrm{a}}$ & $0 \pm 0.00^{\mathrm{a}}$ & $0 \pm 0.00^{\mathrm{a}}$ \\
\hline \multirow{7}{*}{09} & 20 & $6 \pm 0^{b}$ & $5.00 \pm 0.00^{b}$ & $5.67 \pm 0.58^{b}$ & $5.67 \pm 0.58^{b}$ & $5.33 \pm 0.58^{b}$ \\
\hline & 40 & $8.33 \pm 0.58^{c}$ & $7.00 \pm 0.00^{c}$ & $9.33 \pm 1.15^{\mathrm{c}}$ & $7.67 \pm 0.58^{c}$ & $7.00 \pm 0.00^{c}$ \\
\hline & 60 & $13.67 \pm 0.58^{\mathrm{d}}$ & $9.33 \pm 0.58^{\mathrm{d}}$ & $10.67 \pm 0.58^{\mathrm{d}}$ & $9.00 \pm 0.00^{\mathrm{d}}$ & $9.00 \pm 0.00^{\mathrm{d}}$ \\
\hline & 80 & $14.33 \pm 0.58^{\mathrm{d}}$ & $14.00 \pm 0.00^{\mathrm{e}}$ & $14.00 \pm 0.00^{\mathrm{e}}$ & $14.33 \pm 0.58^{\mathrm{e}}$ & $13.67 \pm 0.58^{\mathrm{e}}$ \\
\hline & 100 & $17.67 \pm 0.58^{\mathrm{e}}$ & $18.67 \pm 0.58^{f}$ & $16.00 \pm 1.00^{\mathrm{f}}$ & $18.33 \pm 0.58^{f}$ & $17.67 \pm 0.58^{f}$ \\
\hline & $\mathrm{K}+$ & $18 \pm 0^{\mathrm{e}}$ & $19.00 \pm 0.00^{\mathrm{f}}$ & $18.00 \pm 0.00^{\mathrm{g}}$ & $18.00 \pm 0.00^{\mathrm{f}}$ & $18.00 \pm 0.00^{f}$ \\
\hline & $\mathrm{K}^{-}$ & $0 \pm 0^{\mathrm{a}}$ & $0 \pm 0^{\mathrm{a}}$ & $0 \pm 0^{\mathrm{a}}$ & $0 \pm 0^{\mathrm{a}}$ & $0 \pm 0^{\mathrm{a}}$ \\
\hline \multirow{7}{*}{13} & 20 & $5 \pm 0^{b}$ & $5.33 \pm 0.58^{b}$ & $5 \pm 0^{b}$ & $5 \pm 0^{b}$ & $5.00 \pm 0,00^{b}$ \\
\hline & 40 & $7.67 \pm 0.58^{c}$ & $7.67 \pm 1.15^{\mathrm{c}}$ & $6 \pm 0^{c}$ & $7.67 \pm 0.58^{c}$ & $5.67 \pm 0.58^{c}$ \\
\hline & 60 & $11.67 \pm 0.58^{\mathrm{d}}$ & $12.00 \pm 1.00^{\mathrm{d}}$ & $6.33 \pm 0.58^{c}$ & $11.67 \pm 0.58^{\mathrm{d}}$ & $8.00 \pm 0.00^{\mathrm{d}}$ \\
\hline & 80 & $12.67 \pm 0.58^{\mathrm{e}}$ & $14.67 \pm 0.58^{\mathrm{e}}$ & $8.67 \pm 0.58^{\mathrm{d}}$ & $13 \pm 0^{\mathrm{e}}$ & $8.67 \pm 0.58^{\mathrm{e}}$ \\
\hline & 100 & $12.67 \pm 0.58^{\mathrm{e}}$ & $18.67 \pm 0.58^{\mathrm{f}}$ & $11.33 \pm 1.15^{\mathrm{e}}$ & $16.33 \pm 0.58^{f}$ & $12.00 \pm 0.00^{\mathrm{f}}$ \\
\hline & $\mathrm{K}+$ & $18.33 \pm 0.58^{f}$ & $19.67 \pm 0.58^{f}$ & $18 \pm 0^{f}$ & $18.33 \pm 0.58^{\mathrm{g}}$ & $18.00 \pm 0.00^{\mathrm{g}}$ \\
\hline & $\mathrm{K}^{-}$ & $0 \pm 0^{\mathrm{a}}$ & $0 \pm 0^{\mathrm{a}}$ & $0 \pm 0^{\mathrm{a}}$ & $0 \pm 0^{\mathrm{a}}$ & $0 \pm 0^{\mathrm{a}}$ \\
\hline \multirow{7}{*}{20} & 20 & $5 \pm 0^{b}$ & $5.33 \pm 0.58^{b}$ & $5.67 \pm 1.15^{b}$ & $6.33 \pm 0.58^{b}$ & $6.33 \pm 2.31^{b}$ \\
\hline & 40 & $7.67 \pm 0.58^{c}$ & $8.00 \pm 0.00^{c}$ & $8.67 \pm 2.89^{c}$ & $8.67 \pm 0.58^{b c}$ & $8.00 \pm 1.73^{b c}$ \\
\hline & 60 & $9.67 \pm 0.58^{\mathrm{d}}$ & $11.67 \pm 0.58^{\mathrm{d}}$ & $13.67 \pm 0.58^{d}$ & $13 \pm 0^{\text {bcd }}$ & $11.33 \pm 0.58^{\mathrm{bcd}}$ \\
\hline & 80 & $14 \pm 0^{\mathrm{e}}$ & $14.67 \pm 1.15^{\mathrm{e}}$ & $16.33 \pm 0.58^{\mathrm{e}}$ & $14.33 \pm 0.58^{\mathrm{cd}}$ & $13.00 \pm 0.00^{\mathrm{cd}}$ \\
\hline & 100 & $16.67 \pm 1.15^{\mathrm{f}}$ & $18.00 \pm 0.00^{\mathrm{f}}$ & $18.33 \pm 0.58^{\mathrm{e}}$ & $18.67 \pm 0.58^{\mathrm{de}}$ & $16.33 \pm 1.53^{\mathrm{d}}$ \\
\hline & $\mathrm{K}+$ & $19.33 \pm 0.58^{\mathrm{g}}$ & $18.33 \pm 0.58^{\mathrm{f}}$ & $18.33 \pm 0.58^{\mathrm{e}}$ & $9.67 \pm 7.23^{\mathrm{e}}$ & $14.00 \pm 6.93^{\mathrm{d}}$ \\
\hline & $\mathrm{K}^{-}$ & $0 \pm 0^{\mathrm{a}}$ & $0 \pm 0^{\mathrm{a}}$ & $0 \pm 0^{\mathrm{a}}$ & $0 \pm 0^{\mathrm{a}}$ & $0 \pm 0^{\mathrm{a}}$ \\
\hline \multirow{7}{*}{24} & 20 & $5 \pm 0^{b}$ & $6.67 \pm 1.15^{b}$ & $5.33 \pm 0.58^{b}$ & $5 \pm 0^{b}$ & $5.33 \pm 0.58^{b}$ \\
\hline & 40 & $7.33 \pm 0.58^{c}$ & $8.00 \pm 0.00^{b}$ & $6.33 \pm 0.58^{c}$ & $7.33 \pm 0.58^{c}$ & $8.67 \pm 0.58^{c}$ \\
\hline & 60 & $9.67 \pm 0.58^{\mathrm{d}}$ & $9.00 \pm 0.00^{\mathrm{bc}}$ & $8.67 \pm 0.58^{\mathrm{d}}$ & $12 \pm 1.73^{\mathrm{d}}$ & $13.00 \pm 0.00^{\mathrm{d}}$ \\
\hline & 80 & $13 \pm 0^{\mathrm{e}}$ & $13.67 \pm 0.58^{\mathrm{cd}}$ & $13.67 \pm 0.58^{\mathrm{e}}$ & $13 \pm 0^{\mathrm{d}}$ & $13.67 \pm 0.58^{\mathrm{d}}$ \\
\hline & 100 & $14.33 \pm 0.58^{f}$ & $17.67 \pm 0.58^{\mathrm{d}}$ & $17.67 \pm 0.58^{\mathrm{f}}$ & $15.67 \pm 1.15^{\mathrm{e}}$ & $17.67 \pm 0.58^{\mathrm{e}}$ \\
\hline & $\mathrm{K}+$ & $18 \pm 0^{\mathrm{g}}$ & $14.00 \pm 6.93^{\mathrm{d}}$ & $18 \pm 0^{f}$ & $18.33 \pm 0.58^{\mathrm{f}}$ & $18.00 \pm 0^{\mathrm{e}}$ \\
\hline & $\mathrm{K}^{-}$ & $0 \pm 0^{\mathrm{a}}$ & $0 \pm 0^{\mathrm{a}}$ & $0 \pm 0^{\mathrm{a}}$ & $0 \pm 0^{\mathrm{a}}$ & $0 \pm 0^{\mathrm{a}}$ \\
\hline
\end{tabular}

Numbers followed by the same letter notation indicate no significant difference based on Duncan's test at $\alpha=0.05$ and the number of replications $=3$. Conc.: Concentration; K+: Positive control; $\mathrm{K}-$ : Negative control. 
Statistical analysis showed that the whole supernatant tested at a concentration of $20 \%$ (supernatant / sterile distilled water, v/v) was significantly different from the negative control $(p<0.05)$, with the range of inhibition in the test medium as indicated by a burning zone of $5 \mathrm{~mm}$. This result is relative to the positive control, but at a concentration of $100 \%$ almost all the samples tested had the same inhibitory activity as the positive control and were considered statistically not significantly different $(p>0.05)$. The antimicrobial activity of LAB is due to the production of various compounds that can inhibit the growth of pathogenic bacteria such as lactic acid, hydrogen peroxide $\left(\mathrm{H}_{2} \mathrm{O}_{2}\right)$, carbon dioxide, diacetil, and bacteriocins. The mechanism of inhibiting the growth of pathogenic bacteria by LAB is through a decrease in $\mathrm{pH}$ caused by the secretion of organic acid compounds. Organic acid molecules can enter through the cell membrane of pathogenic bacteria to change the permeability of the cell membrane and cause protein instability in cells and the material transport system in pathogenic bacteria is still disrupted.

$\mathrm{H}_{2} \mathrm{O}_{2}$ produced by LAB can cause denaturation of enzymes in pathogenic bacteria and produce free radicals such as superoxide and hydroxyl which can damage DNA. In addition, $\mathrm{H}_{2} \mathrm{O}_{2}$ can oxidize sulfhydryl groups which cause membrane lipid peroxidation, resulting in increased membrane permeability and as a precursor for the production of bactericidal free radicals [8]. Lactic acid has antimicrobial properties because it can interfere with cell membrane work, inhibit transport activity, reduce intracellular $\mathrm{pH}$ and inhibit various metabolic functions [32]. Bacteriocins in LAB can change membrane permeability so that they interfere with membrane transport or eliminate proton movement which results in inhibition of energy production and protein or nucleic acid biosynthesis [33]. The antimicrobial compounds produced by LAB such as those produced by L. plantarum NS are reported to be able to inhibit the growth of food pathogens such as E. coli, B. cereus, L. monocytogenes, S. aureus, and $S$. thypimurium [5].

\section{Conclusions}

In conclusion, this study revealed a potential LAB isolated from Sumbawa White Honey as antimicrobial compounds against pathogens. The 16s rRNA analysis identified Enterococcus faecium species with identity above $90 \%$ of 5 isolated LAB. The species identified could ferment carbon sources present in honey, and this data indicated a potential source LAB in the raw material food for alternative antibacterial production. Further improvement is also needed to analyze the metabolite active compound and its activity for antioxidant, antidiabetic, anticancer activity since LAB in raw food is an important source for alternative therapy.

\section{Acknowledgments}

Our gratitude goes to the Head of the Biotechnology Laboratory of Sumbawa University of Technology and the Head of the Applied Genetic Engineering and Protein Design laboratory, the Biological Product Development Unit, Biotechnology Research Center, Indonesian Institute of Sciences (LIPI), and the Senior High School SAMAWA Cendekia for financial assistance and equipment assistance in this research process. 


\section{References}

[1] SR Fitrianingsih, A Khairat and R Choesrina. Antibacterial activity of bitter black honey and sweet black honey against Escherichia coli and Staphylococcus aureus. J. Farmasi Galenika 2014; 1, 32 7.

[2] U Pato. The potential of lactic acid bacteria isolated from curds to reduce the risk of cancer. J. Natur Indonesia 2003; 5, 162-6.

[3] S Romadon and S Margino. Isolation and characterization of lactic acid bacteria from bacteriocinproducing shrimp intestines as antibacterial agents in fishery products. J. Saintek Perikanan 2012; 8.

[4] Y Widyastuti and E Sofarianawati. Lactic acid bacteria, Enterococcus sp. isolated from the digestive tract of livestock. J. Mikrobiol. Indones. 1999; 4, 50-3.

[5] Desniar, I Rusmana, A Suwanto and NR Mubarik. Characterization of lactic acid bacteria isolated from an Indonesian fermented fish (bekasam) and their antimicrobial activity against pathogenic bacteria. Emirates J. Food Agr. 2013; 25, 489-94.

[6] MM Theron and JFR Lues. Mechanisms of microbial inhibition. In: MM Theron (Ed.). Organic acids and food preservation. CRC Press, 2011, p. 117-50.

[7] B Manguntungi, A Sari, R Chaidir, I Islam, L Vanggy, N Sufiyanti, M Fateeh, U Whatin, U Pratiwi and $\mathrm{W}$ Kusuma. Isolation and characterization of black honey lactic acid bacteria and their potential as an antimicrobial compound. J. Pendidikan Biologi Undiksha 2020; 2020, 7.

[8] RS Hadioetomo. Basic microbiology in technical practices and basic laboratory procedures, Gramedia, Jakarta, 1993.

[9] E Purwijantiningsih. Uji antibakteri yoghurt sinbiotik terhadap beberapa bakteri patogen enterik. Biota: Jurnal Ilmiah Ilmu-Ilmu Hayati 2011; 16, 173-7.

[10] DK Lahiri and B Schnabe. DNA isolation by a rapid method from human blood samples: Effects of $\mathrm{MgCl}_{2}$, EDTA, storage time, and temperature on DNA yield and quality. Biochem. Genet. 1993; 31, 321-8.

[11] TC Olofsson and A Vásquez. Detection and identification of a novel lactic acid bacterial flora within the honey stomach of the honeybee Apis mellifera. Curr. Microbiol. 2008; 57, 356-63.

[12] M Gilliam. Identification and roles of non-pathogenic microflora associated with honey bees. FEMS Microbiol. Lett. 1997; 155, 1-10.

[13] ZP Rokop, MA Horton and ILG Newton. Interactions between cooccurring lactic acid bacteria in honey bee hives. Appl. Environ. Microbiol. 2015; 81, 7261-70.

[14] A Vasquez, E Forsgren, I Fries, RJ Paxton, E Flaberg, L Szekely and TC Olofsson. Symbionts as major modulators of insect health: Lactic acid bacteria and honeybees. PLos One 2012; 7, e33188.

[15] P Molan. The antibacterial properties of honey. Chem New Zealand 1995; 59, 10-4.

[16] BY Bulgasem, MN Lani, Z Hassan, WMW Yusoff and SG Fnaish. Antifungal activity of lactic acid bacteria strains isolated from natural honey against pathogenic Candida species. Mycobiology 2016; 44, 302-9.

[17] JCD Man, D Rogosa and ME Sharpe. A medium for the cultivation of lactobacilli. J. Appl. Bacteriol. 1960; 23, 130-5.

[18] U Schillinger and WH Holzapfel. Culture media for lactic acid bacteria. Progr. Ind. Microbiol. $2003 ; 37,127-40$

[19] V Bottazzi. An introduction to rod-shaped lactic-acid bacteria. Biochimie 1988; 70, 303-15.

[20] ME Stiles and WH Holzapfe. Lactic acid bacteria of foods and their current taxonomy. Int. J. Food Microbiol. 1997; 36, 1-29.

[23] R Whittenbury. Hydrogen peroxide formation and catalase activity in the lactic acid bacteria. Microbiology 1964; 35, 13-26.

[24] RJ Weston and LK Brocklebank. The oligosaccharide composition of some New Zealand honeys. Food Chem. 1999; 64, 33-7.

[25] CG Nettles and SF Barefoot. Biochemical and genetic characteristics of bacteriocins of foodassociated lactic acid bacteria. J. Food Prot. 1993; 56, 338-56. 
http://wjst.wu.ac.th

[26] JD Evans and TN Armstrong. Antagonistic interactions between honey bee bacterial symbionts and implications for disease. BMC Ecol. 2006; 21, 4.

[27] MA Abdel-Rahman, Y Tashiro and K Sonomoto. Recent advances in lactic acid production by microbial fermentation processes. Biotechnol. Adv. 2013; 31, 877-902.

[28] G Reddy, MD Altaf, BJ Naveena, M Venkateshwar and EV Kumar. Amylolytic bacterial lactic acid fermentation: A review. Biotechnol. Adv. 2008; 26, 22-34.

[29] TR Shamala, Y Shri Jyothi and P Saibaba. Stimulatory effect of honey on multiplication of lactic acid bacteria under in vitro and in vivo conditions. Lett. Appl. Microbiol. 2000; 30, 453-5.

[30] A Khajuria, AK Praharaj, N Grover and M Kumar. First report of an Enterobacter ludwigii isolate coharboring NDM-1 and OXA-48 carbapenemases. Antimicrob. Agents Chemother. 2013; 57, 518990.

[31] M Anuradha. Leclercia Adecarboxylata isolation: Case reports and review. J. Clin. Diagn. Res. 2014; 8, DD03-DD04.

[32] B Manguntungi, DS Saputri, AZ Mustopa, N Ekawati, M Nurfatwa, A Prastyowati, S Irawan, LR Vanggy and KA Fidien. Antidiabetic, antioxidants and antibacterial activities of Lactic Acid Bacteria (LAB) from Masin (Fermented Sauces from Sumbawa, West Nusa Tenggara, Indonesia). Ann. Bogorienses 2020; 24, 27-34.

[33] B Manguntungi, A Sari, R Chaidir, I Islam, L Vanggy, N Sufiyanti, M Fateeh, U Whatin, U Pratiwi and W Kusuma. Isolation, characterization and antibacterial activity of indigenous LAB from Trigona spp. originating from the district of Sumbawa. Biotropika J. Trop. Biol. 2020; 2020, 8. 